\title{
Research on Competitive Advantages of Commercial Banks of China
}

\author{
Yu Song ${ }^{1, \text { a }}$ \\ ${ }^{1}$ School of Mathematics and Information Sciences, Yantai University, Yantai, 264000, China
}

Keywords: Commercial banks, Evaluation standards, Competitive power, Index system

\begin{abstract}
With the accelerated pace of global economic integration and the implementation of "Belt and Road" policy of China, the degree of opening to the outside world is gradually increasing. China's banking industry is directly facing the international mature financial market, and the pressure of competition becomes bigger and bigger. This paper aims to refer to many international and domestic evaluation standards to construct a reasonable evaluation index system and make a reasonable evaluation of the competitiveness of China's listed commercial banks. The paper also makes the relevant analysis for the evaluation results.
\end{abstract}

\section{Research Background and Significance}

Research Background. At present, China has many commercial banks listed on the stock exchange of Shanghai and Shenzhen, and the rapid development of commercial banks makes the competition in the banking industry more and more intense. At the same time, with the accelerated pace of global economic integration and the implementation of "Belt and Road" policy of China, the degree of opening to the outside world is gradually increasing.

It is a common concern of the governments and bank system how to effectively evaluate the competitive power of the listed commercial banks in China and find the solutions to enhance the competitive power according to the difference of the competitive advantages.

Research Significance. At present, China has formed a comprehensive commercial bank system, including four big state-owned commercial banks, some joint-stock commercial banks as well as many urban commercial banks and urban rural credit cooperatives. This article will objectively evaluate the competitive level of domestic listed commercial banks to help them to understand their own shortcomings and enhance their competitive advantages to provide important references for their development.

\section{Theoretical Analysis of the Subject}

The competitive power of the commercial banks is composed of profit margins, asset liquidity management, capital adequacy degree, enterprise management level and so on. The profit margins of the commercial banks can increase the security to enhance the customer's acceptance and appeal to more customers.

\section{Case Study of the Subject}

The selected six commercial banks are composed Pingan Bank listed in Shenzhen Exchanges and China Minsheng Bank, China Merchants Bank, Huaxia Bank, Bank of China and Industrial Bank Co., Ltd listed in Shanghai Exchanges. Among them, Shenzhen Development Bank, as one of the predecessors of Pingan Bank is the first listed commercial bank in China.

Analysis of Capital Adequacy. The capital adequacy of each listed commercial banks of China in 2016 is shown in Table 1. 
Table 1. Capital adequacy of listed commercial banks of China in 2016

\begin{tabular}{|lccc|}
\hline & Capital adequacy $(\%)$ & Equity/Asset $(\%)$ & Equity/Loans (\%) \\
\hline Pingan Bank & 11.53 & 6.85 & 14.07 \\
China Minsheng Bank & 11.73 & 5.97 & 14.31 \\
China Merchants Bank & 12 & 6.79 & 12.37 \\
Huaxia Bank & 11.36 & 6.5 & 12.57 \\
Bank of China & 14.28 & 8.19 & 14.91 \\
Industrial Bank Co., Ltd & 12.02 & 5.82 & 17.66 \\
\hline
\end{tabular}

Data sources: annual reports of the banks in the above table in 2016

Analysis of Profit Margins. The profit margin of each listed commercial banks of China in 2016 is shown in Table 2.

Table 2. Profit margins of listed commercial banks of China in 2016

\begin{tabular}{|lcccc|}
\hline & Return of asset (\%) & $\begin{array}{c}\text { Capital recovery } \\
\text { rate }(\%)\end{array}$ & Profit margin (\%) & Asset utilization(\%) \\
\hline Pingan Bank & 0.77 & 11.18 & 23.77 & 3.65 \\
China Minsheng Bank & 0.94 & 13.86 & 31.43 & 2.63 \\
China Merchants Bank & 1.09 & 15.47 & 29.84 & 3.52 \\
Huaxia Bank & 0.9 & 12.91 & 30.86 & 2.72 \\
Bank of China & 1.01 & 12.38 & 38.06 & 2.66 \\
Industrial Bank Co., Ltd & 0.95 & 15.33 & 34.59 & 2.58 \\
\hline
\end{tabular}

Data sources: annual reports of the banks in the above table in 2016

Analysis of Asset Quality. Generally speaking, the more the asset quality is, the bigger the competitive power of the commercial bank is. The asset quality of listed commercial banks of China in 2016 is shown in Table 3.

Table 3. Asset quality of listed commercial banks of China in 2016

\begin{tabular}{|lccc|}
\hline & $\begin{array}{c}\text { Non-performing loan } \\
\text { ratio (\%) }\end{array}$ & $\begin{array}{c}\text { Provisioning coverage ratio (\%) } \\
\text { n ratio }(\%)\end{array}$ & $\begin{array}{c}\text { Loan-to-provisio } \\
\text { Pingan Bank }\end{array}$ \\
China Minsheng Bank & 1.74 & 155.37 & 2.71 \\
China Merchants Bank & 1.68 & 155.4 & 3.37 \\
Huaxia Bank & 1.87 & 180.02 & 2.65 \\
Bank of China & 1.67 & 158.73 & 2.87 \\
Industrial Bank Co., Ltd & 1.46 & 162.82 & 3.48 \\
\hline
\end{tabular}

Data sources: annual reports of the banks in the above table in 2016

Analysis of Asset Liquidity. The liquidity performances of sample commercial banks in the paper are shown in Table 4. 
Table 4. Asset Liquidity situation of listed commercial banks of China in 2016

\begin{tabular}{|lrr|}
\hline \multicolumn{2}{|c|}{ Liquidity ratio $(\%)$} & Loan-to-deposit ratio (\%) \\
\hline Pingan Bank & 47.62 & 75.21 \\
\hline China Minsheng Bank & 39.64 & 79.86 \\
China Merchants Bank & 59.42 & 85.79 \\
Huaxia Bank & 31.45 & 88.92 \\
Bank of China & 45.6 & 77.08 \\
Industrial Bank Co.,Ltd & 59.35 & 72.5 \\
\hline
\end{tabular}

Data sources: annual reports of the banks in the above table in 2016

\section{Index Score and Comprehensive Score}

Through the above analysis of each secondary index of the six primary indices, we obtain the individual scores and total scores of each primary index of the commercial banks according to the evaluation index system of the competitiveness of China's commercial banks constructed in the paper. The results are shown in Table 5.

Table 5. Index score of listed commercial banks of China in 2016

\begin{tabular}{|c|c|c|c|c|c|c|c|c|}
\hline $\begin{array}{l}\text { Primary } \\
\text { index }\end{array}$ & Secondary index & $\begin{array}{l}\text { Full } \\
\text { marks }\end{array}$ & $\begin{array}{l}\text { Pingan } \\
\text { Bank }\end{array}$ & $\begin{array}{l}\text { China } \\
\text { Minsheng } \\
\text { Bank }\end{array}$ & $\begin{array}{l}\text { China } \\
\text { Merchant } \\
\text { s Bank }\end{array}$ & $\begin{array}{l}\text { Huaxia } \\
\text { Bank }\end{array}$ & $\begin{array}{l}\text { Bank } \\
\text { of } \\
\text { China }\end{array}$ & $\begin{array}{l}\text { Industria } \\
\text { l Bank } \\
\text { Co., Ltd }\end{array}$ \\
\hline \multirow{4}{*}{$\begin{array}{l}\text { Capital } \\
\text { adequacy } \\
\text { degree }\end{array}$} & Capital adequacy & 100 & 45.3 & 47.3 & 50 & 43.6 & 72.8 & 50.2 \\
\hline & Equity/Asset & 60 & 50.8 & 43.76 & 50.32 & 48 & 60 & 42.56 \\
\hline & Equity/Loans & 40 & 40 & 40 & 40 & 40 & 40 & 40 \\
\hline & Total & 200 & 136.1 & 131.06 & 140.32 & 131.6 & 172.8 & 132.76 \\
\hline \multirow{5}{*}{$\begin{array}{l}\text { Profit } \\
\text { margins }\end{array}$} & Return of asset & 60 & 38.2 & 48.4 & 57.4 & 46 & 52.6 & 49 \\
\hline & Capital recovery rate & 50 & 12.95 & 19.65 & 23.68 & 17.28 & 15.95 & 23.33 \\
\hline & Profit margin & 50 & 50 & 50 & 50 & 50 & 50 & 50 \\
\hline & Asset utilization & 40 & 13.2 & 5.04 & 12.16 & 5.76 & 5.28 & 4.64 \\
\hline & Total & 200 & 114.35 & 123.09 & 143.24 & 119.04 & 123.83 & 126.97 \\
\hline \multirow{4}{*}{ Asset quality } & $\begin{array}{l}\text { Non-performing loan } \\
\text { ratio }\end{array}$ & 80 & 78.72 & 79.04 & 78.03 & 79.09 & 80 & 79.2 \\
\hline & $\begin{array}{l}\text { Provisioning coverage } \\
\text { ratio }\end{array}$ & 60 & 60 & 60 & 60 & 60 & 60 & 60 \\
\hline & Loan-to-provision ratio & 60 & 15.1 & 14.2 & 21.7 & 14.5 & 16.7 & 22.8 \\
\hline & Total & 200 & 153.82 & 153.24 & 159.73 & 153.59 & 156.7 & 162 \\
\hline \multirow{3}{*}{$\begin{array}{l}\text { Asset } \\
\text { liquidity }\end{array}$} & Liquidity ratio & 100 & 41.52 & 70.56 & 0 & 37.8 & 49.6 & 0 \\
\hline & Loan-to-deposit ratio & 100 & 5.16 & 0 & 0 & 0 & 0 & 16 \\
\hline & Total & 200 & 46.68 & 70.56 & 0 & 37.8 & 49.6 & 16 \\
\hline \multirow{4}{*}{$\begin{array}{l}\text { Management } \\
\text { level }\end{array}$} & Shareholder strength & 50 & 40 & 30 & 40 & 40 & 50 & 40 \\
\hline & Market sensitivity & 100 & 85 & 100 & 100 & 85 & 100 & 85 \\
\hline & $\begin{array}{l}\text { Internal control and } \\
\text { management } \\
\text { standardization }\end{array}$ & 50 & 38 & 38 & 50 & 38 & 50 & 50 \\
\hline & Total & 200 & 163 & 168 & 190 & 163 & 200 & 175 \\
\hline \multirow{3}{*}{$\begin{array}{l}\text { Enterprise } \\
\text { ability }\end{array}$} & Innovation ability & 100 & 60 & 100 & 100 & 80 & 100 & 80 \\
\hline & Brand Influence & 100 & 80 & 80 & 100 & 80 & 100 & 80 \\
\hline & Total & 200 & 140 & 180 & 200 & 160 & 200 & 160 \\
\hline
\end{tabular}


According to the index score of each commercial bank and the index weight set in the previous section, we obtain the comprehensive value of each bank. The results are shown in Table 6.

Table 6. Comprehensive score of listed commercial banks of China in 2016

\begin{tabular}{|lccccccc|}
\hline Primary index & $\begin{array}{c}\text { Weight } \\
(\%)\end{array}$ & $\begin{array}{c}\text { Pingan } \\
\text { Bank }\end{array}$ & $\begin{array}{c}\text { China } \\
\text { Minsheng } \\
\text { Bank }\end{array}$ & $\begin{array}{c}\text { China } \\
\text { Merchants } \\
\text { Bank }\end{array}$ & $\begin{array}{c}\text { Huaxia } \\
\text { Bank }\end{array}$ & $\begin{array}{c}\text { Bank of } \\
\text { China }\end{array}$ & $\begin{array}{c}\text { Industrial } \\
\text { Bank Co., } \\
\text { Ltd }\end{array}$ \\
Capital adequacy degree & 10 & 6.81 & 6.56 & 7.02 & 6.58 & 8.64 & 6.64 \\
Profit margins & 30 & 17.16 & 18.47 & 21.49 & 17.86 & 18.58 & 19.05 \\
Asset quality & 20 & 15.38 & 15.33 & 15.98 & 15.36 & 15.67 & 16.2 \\
Asset liquidity & 10 & 2.34 & 3.53 & 0 & 1.89 & 2.48 & 0.8 \\
Management level & 15 & 12.23 & 12.6 & 14.25 & 12.23 & 15 & 13.13 \\
Enterprise ability & 15 & 10.5 & 13.5 & 15 & 12 & 15 & 12 \\
Total & 100 & 64.4 & 69.98 & 73.73 & 65.91 & 75.37 & 67.81 \\
\hline
\end{tabular}

According to the comprehensive score table, the score rank order of the six banks is: Bank of China (75.37), China Merchants Bank (73.73), China Minsheng Bank (69.98), Industrial Bank Co., Ltd (67.81), Huaxia Bank (65.91) and Pingan Bank (64.40). The highest comprehensive score bank in the sample banks is Bank of China, and the lowest is Pingan Bank.

Bank of China occupies to the first place in the six sample banks with the mark of 75.37. It has strong advantages in the aspects of capital adequacy degree, management level and enterprise ability. The stable operation of Bank of China lies in the improvement of enterprise management level. It carries out the development concept of "innovation, coordination, green development, opening up and sharing”, achieving good performance in optimizing the quality and efficiency of service and accelerating the innovation of business model and risk management. China Merchants Bank occupies to the first place in the single item of profit margins and enterprise ability. It has affinities with the new strategic direction of "Light Bank", which can enhance the asset utilization. However, the control ability of non-performing loan is decreasing and the asset quality has declined compared with 2015. Compared with Bank of China and China Merchants Bank, the capital adequacy degrees of China Minsheng Bank, Industrial Bank Co., Ltd, Huaxia Bank and Pingan Bank are still significant gap. The low loan-to-provision ratio of China Minsheng Bank in the asset quality aspect may lead to negative influence on the asset utilization. In the regard of liquidity, the problem of too high liquidity of Industrial Bank Co., Ltd would bring about negative influence on the capital utilization efficiency.

The management level of Huaxia Bank is relatively low, needing the further improvement of internal control management system and the professional overall management to orderly enhance the ability of risk management and control.

Pingan Bank ranks the last among the selected banks, and its rating indices are seriously imbalanced. The bank needs to make relatively big adjustments in its financial strategy in the future. The product structure needs to be more reasonable and the management and innovation ability need to be optimized.

\section{References}

[1] Zhang Hu, Pan Pan, Fan Lili. Analyses and Forecast the Chinese Commercial Banks' Competitiveness from the Effective Perspective [J]. Soft Science, 2016, 30(2): 130-133+138.

[2] Li Qiong, Cai Qian. An Analysis on the Competitive Environment for Commercial Banks in Internet Finance Era [J]. Credit Reference, 2015(7): 68-71.

[3] Ma Yi. Big Data Encountered by Commercial Banks: Challenges and Competitive Strategy Evolution [J]. Credit Reference, 2014(2): 75-78. 
[4] Zhang Ying wei, Hu Xiaodong. Study on the Competitive Power of Cross-strait Commercial Banks on the Basis of Analytic Hierarchy Process [J]. Asia-pacific Economic Review, 2014(4): 91-96. 